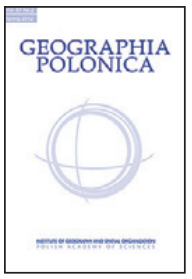

\title{
CHANGES IN THE RURAL LANDSCAPE OF THE POLISH SUDETY MOUNTAINS IN THE POST-WAR PERIOD
}

\section{Agnieszka Latocha}

\author{
University of Wrocław \\ Faculty of Earth Science and Environmental Management \\ pl. Uniwersytecki 1, 50-137 Wrocław: Poland \\ e-mail address: agnieszka.latocha@uni.wroc.pl
}

\begin{abstract}
In the post-war period, the area of the Sudety Mountains (also known in English as the Sudetic Mountains or the Sudetes) has been subject to two main trends regarding the transformation of the landscape in rural areas. In a first phase - intensifying above all in the period from the 1950s through to the 1970s - it was possible to observe an abrupt depopulation process, most especially affecting the areas at higher elevations. The result of this was the disappearance of many villages, or else marked decreases in numbers of both inhabitants and buildings. Knock-on effects from that included the onset of secondary succession on abandoned fields, with the result that new areas of forest have emerged in many parts of the contemporary landscape that were once cultivated fields or pastureland.

Equally, from the end of the 1990s, a new trend as regards the management of rural areas in the Sudetes began to make itself apparent. This entailed an intensive development of single-family building construction, including in the form of summer homes. This development has unfortunately been chaotic in many areas, making no reference to the spatial structure originating in villages established far earlier; the result being disruption of the spatial order. At the same time, there has been no return to villages' former functions, and nor is it possible to observe any increase in the area put to use as farmland. Nevertheless, it is true to say that many areas of what had been waste ground undergoing secondary succession have now been brought back under management, not least in connection with the implementation of joint agricultural and environmental programmes of the European Union.

Various actions are today underway with a view to the typical cultural landscape of the Sudety Mountains (including the Jelenia Góra Basin) being reinstated and protected, with the rural aspect to the mountain landscape being promoted as an attribute favourable to further regional development (inter alia of the Kłodzko region).
\end{abstract}

\section{Key words}

cultural landscape - rural landscape - land-use changes - upgrading and protection of the landscape - Sudety Mountains

\section{Introduction}

The socioeconomic changes a given region is subject to also soon find their reflection in changes to the functional and spatial structure of its landscape. Mountain areas in particular display intensive dynamics as regards changes in the landscape, because the relief is characterised by high energy, and hence by very active processes that are capable of shaping and modifying relief, reacting rapidly as they do so to changing management conditions in the areas concerned.

Over the last several decades, many mountain and upland regions of Europe have been witnessing 
an active depopulation process affecting the most elevated parts in particular, as well as a regression of settlement and an abandonment of the agricultural utilisation of land (e.g. Baldock et al. 1996; MacDonald et al. 2000). However, Poland is seen to differ from most other countries in the abrupt course these processes have followed, this reflecting the simultaneous presence of unfavourable natural (environmental) conditions and political or systemic transformations, including even the changes in borders and large-scale resettlement actions that took place in the aftermath of the World War II. The most perceptible processes of this kind have been noted in the Bieszczady and Sudety Mountains (Latocha 2007; Wolski 2007, 2009).

The area of the Sudety Mountains has been subject to several distinct, if non-uniform post-war trends in regard to changes in the landscape of their rural areas, and following on from transformations affecting both society and the economy in the Poland of this era. An almost-full exchange of populations took place after World War II, with the attendant arrival of large numbers of new settlers constituting a turning point where the development of land-use was concerned, and hence also tangible changes in the region's landscape. The subject matter of depopulation in the Sudetes and associated land-use changes has been dealt with in many settlement-geography and spatial-management-related studies (Plewniak 1978; Salwicka 1978, 1983; Jerkiewicz 1983; Miszewska 1989; Ciok 1994, 1995; Latocha 2007). Indeed, the disappearance of rural settlement - with all its economic and ecological consequences - came to be regarded as one of the main problems facing the Sudety Mountain region (Ciok 1991).

However, as the old millennium came to an end and a new one began, the trends that had held sway earlier began to undergo modification, and this clearly in line with socioeconomic and ownership-related changes ongoing in Poland. What was most clear at this point was the onset of a renewed construction 'boom' when it came to single-family homes in rural areas of the mountains, these including summer homes, buildings serving recreational purposes, and even some year-round

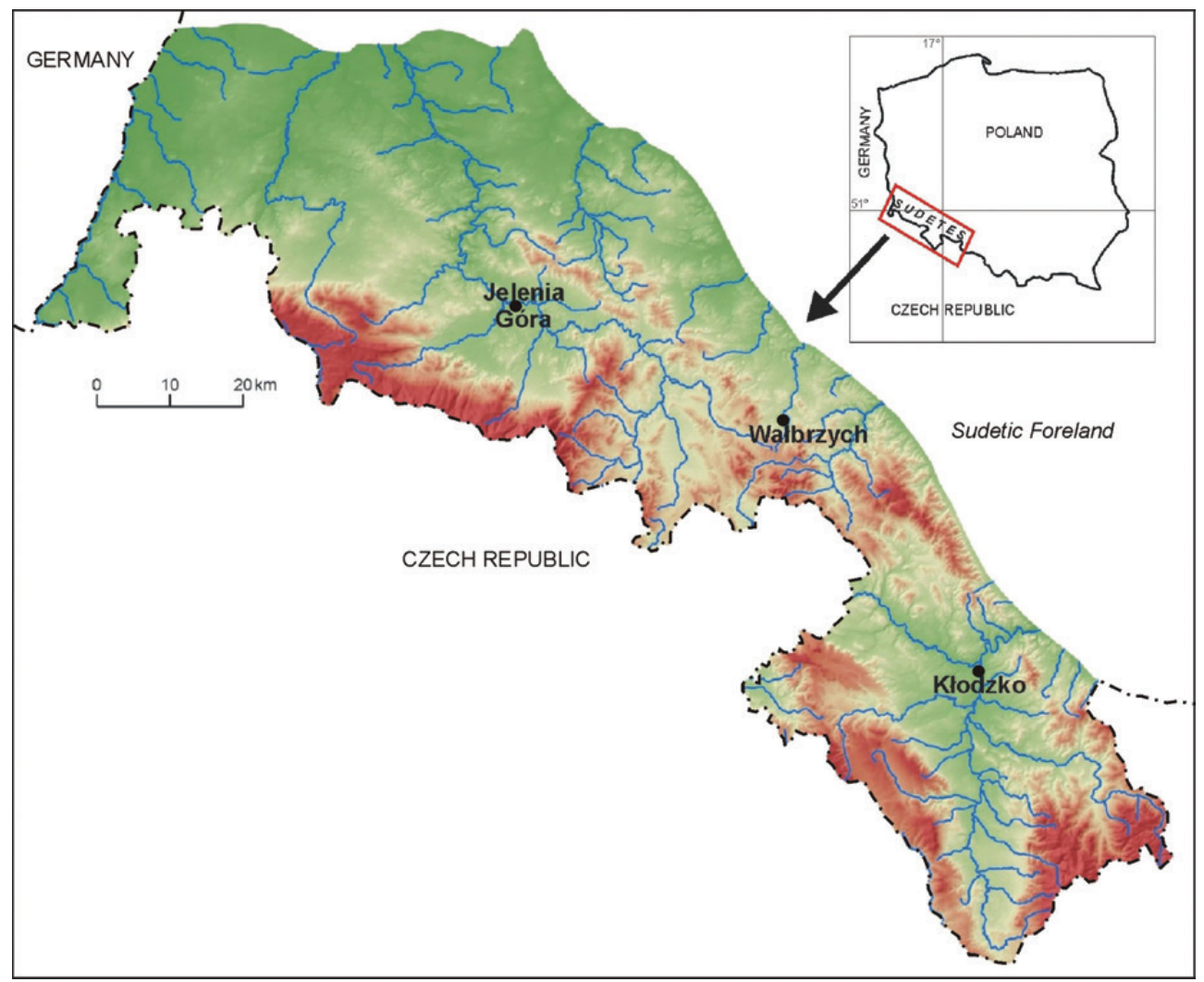

Figure 1. Location of study area. 
dwellings (Potocki 2000; Bryś \& Ojrzyńska 2010; Latocha 2010 among others). There was also a clear process by which older buildings (often featuring heritage architecture) began to be renovated (Korzeń 2006). In turn, Poland's accession to the European Union in 2004 in general (and in particular the extending of environment-related direct payments to farmers, and the possibilities for participation in joint agricultural/environmental programmes) led to distinct changes in land-use (Mastalska-Cetera 2006, 2008).

Bearing the aforesaid trends in mind, it is possible to regard the Sudetes as offering a very clear and legible example of successive political, social and economic transformations finding their reflection in modifications to landscape structure. The scale of these transformations goes together with the complex history of the region in question to make this a quite unique case.

The work described in this paper has thus sought to offer a qualitative and quantitative characterisation of ongoing trends where the landscape of the whole range of the Polish Sudety Mountains is concerned (Fig. 1), and in regard to the post-war period. A secondary aim beyond that has been to describe and account for the more-local-level changes characterising selected areas of the range in question. The methodology applied with this aim in mind extended to the analysis of historical and archival (mainly statistical and cartographic) materials (e.g. topographic Messtischblätt maps at a scale of $1: 25,000$, dating back to the late 19th and early 20th centuries). Beyond that, fieldwork was also carried out to map forms of relief and settlement linked genetically with human activity, to verify the current state of use and management where selected areas were concerned, and to define the scope of the secondary vegetational succession taking place on unused arable land.

\section{Changes in different elements of the rural landscape}

\section{Changes in land use}

One of the leading elements to landscape structure obviously concerns type of land use. In the post-war period, the means of managing land in the Sudety Mountains changed very markedly. There was above all a considerable decline in the proportion of all land given over to arable cultivation, this being at the expense of an increase in forest cover and the area of pastureland (Tab. 1) The curbing of the use of land to grow crops was associated with two processes. In the first place, the World War II had given rise to circumstances in which almost the entire population in the area of the Sudety Mountains was subject to an 'exchange'. Specifically, the place of a core population that was essentially German (and that was well able to cope with farming in the mountains) was taken by settlers mainly originating in the lowland areas of Central Poland, as well as land in the far south-east of pre-war Poland that lay within what is today Ukraine. These people lacked the skill necessary to engage in crop-growing in the difficult conditions of a montane environment (Walczak 1968). While the size of the population pre-war and immediately post-war was similar, a strong depopulation trend had set in as early as in the 1950s, the main phase of this continuing into the 1970s (though today too, it is possible to note a permanent departure of young people from the Sudetes - Ciok 1995). One result of the loss of population from mountain areas was the abandonment of former farmland. This inevitably first affected land least suitable for use or management, which is to say the more-elevated upper sections of valleys and the steepest slopes, where the potential threat posed by soil erosion is greatest ( $\mathrm{Bac}$ 1948; Fatyga 1998).

The areas abandoned were naturally subject to progressing secondary succession of their vegetation, the impact of this being a distinct change in the landscape over recent decades, with a lowering of altitude of the field-forest boundary and encroachment of forests on to formerly agricultural land (Fatyga \& Górecki 2001). From one commune (local-level administrative unit) to another, the increases in the shares of land under forest have been in the range 5 to $17 \%$ over the period since the end of World War II (Tab. 1). However, where smaller areas (like individual drainage basins) are concerned, local environmental conditions may have favoured far more extreme trends, with some areas even experiencing increases of forest cover of the order of $200 \%$ over the last 100 years (Latocha 2007).

The different stages to which secondary succession has proceeded in different areas contributes to the emergence of today's very diversified landscape, in which there are numerous ecotones.

Changes in land-use on slopes also brought about change in the course of slope processes, 
Table 1. Land use change in the post-war period in the selected rural and municipal-rural communes in Kłodzko Region.

\begin{tabular}{|c|c|c|c|c|c|c|}
\hline \multirow[b]{2}{*}{ Years } & \multicolumn{6}{|c|}{ Land use (\%) } \\
\hline & arable land & orchards & meadows & pastures & forests & $\begin{array}{c}\text { other and } \\
\text { wastelands }\end{array}$ \\
\hline \multicolumn{7}{|c|}{ Nowa Ruda - rural commune } \\
\hline $\begin{array}{l}1949 \\
2005\end{array}$ & $\begin{array}{l}51.2 \\
24.8 \\
\end{array}$ & $\begin{array}{l}1.0 \\
0.2\end{array}$ & $\begin{array}{r}9.9 \\
12.6\end{array}$ & $\begin{array}{r}3.0 \\
13.0\end{array}$ & $\begin{array}{l}26.0 \\
41.8\end{array}$ & $\begin{array}{l}8.8 \\
7.4\end{array}$ \\
\hline \multicolumn{7}{|c|}{ Kłodzko - rural commune } \\
\hline $\begin{array}{l}1949 \\
2005\end{array}$ & $\begin{array}{l}54.9 \\
49.6 \\
\end{array}$ & $\begin{array}{l}0.5 \\
0.2\end{array}$ & $\begin{array}{l}9.0 \\
8.3\end{array}$ & $\begin{array}{l}6.8 \\
8.3\end{array}$ & $\begin{array}{l}19.2 \\
24.2\end{array}$ & $\begin{array}{l}9.5 \\
9.4\end{array}$ \\
\hline \multicolumn{7}{|c|}{ Lewin Kłodzki - rural commune } \\
\hline $\begin{array}{l}1949 \\
2005\end{array}$ & $\begin{array}{l}41.6 \\
13.8\end{array}$ & $\begin{array}{l}0.1 \\
0.3\end{array}$ & $\begin{array}{l}10.1 \\
12.0\end{array}$ & $\begin{array}{r}7.0 \\
19.3\end{array}$ & $\begin{array}{l}29.0 \\
46.4\end{array}$ & $\begin{array}{l}9.3 \\
8.1\end{array}$ \\
\hline \multicolumn{7}{|c|}{ Radków - municipal-rural commune } \\
\hline $\begin{array}{l}1949 \\
2005\end{array}$ & $\begin{array}{l}58.2 \\
41.8\end{array}$ & $\begin{array}{l}0.8 \\
0.1\end{array}$ & $\begin{array}{l}9.1 \\
7.4\end{array}$ & $\begin{array}{l}3.8 \\
8.2\end{array}$ & $\begin{array}{l}21.0 \\
35.3\end{array}$ & $\begin{array}{l}7.1 \\
7.1\end{array}$ \\
\hline
\end{tabular}

Source: own research on the basis of the statistical data from GUS (Central Statistical Office) in Wrocław and from the State Archive in Wrocław-Kamieniec Zabkowicki.

first and foremost a clear curbing of soil erosion on slopes subject to the natural closure of plant cover and emergence of forest. Consequent changes in fluvial processes also ensued (Latocha 2009). In the post-war era, the brooks of the Sudety Mountains have been characterised by a distinct tendency for bottom erosion and downcutting to take place, this being a result of increasingly limited supplies of slope material available for channel transport. Many places have also witnessed a renaturalisation of watercourses, thanks to a lack of the more regular clearing and regulation activity that characterised earlier periods.

Relict elements of an earlier agricultural landscape to be found in what are today forest areas take the form of various anthropogenic aspects of relief, including terraces and piles of stones removed from fields (Fig. 2), and there are also still fruit trees to be met with within the monocultures of spruce that otherwise prevail in the Sudetes.

Notwithstanding the above, the period of the most recent years has been associated with some reversal of trends as regards land use, in association with the mobilisation of the agri-environmental programmes of the European Union, and the direct payments to farmers for maintaining as high a level of biodiversity in mountain areas as possible (Mastalska-Cetera 2006, 2008). Locally at least, the results of this have been an arresting of the process of secondary vegetational succession, with many places noting a return of land left fallow for some years to utilisation (mainly mowing and use as meadow to be mown or pasture).

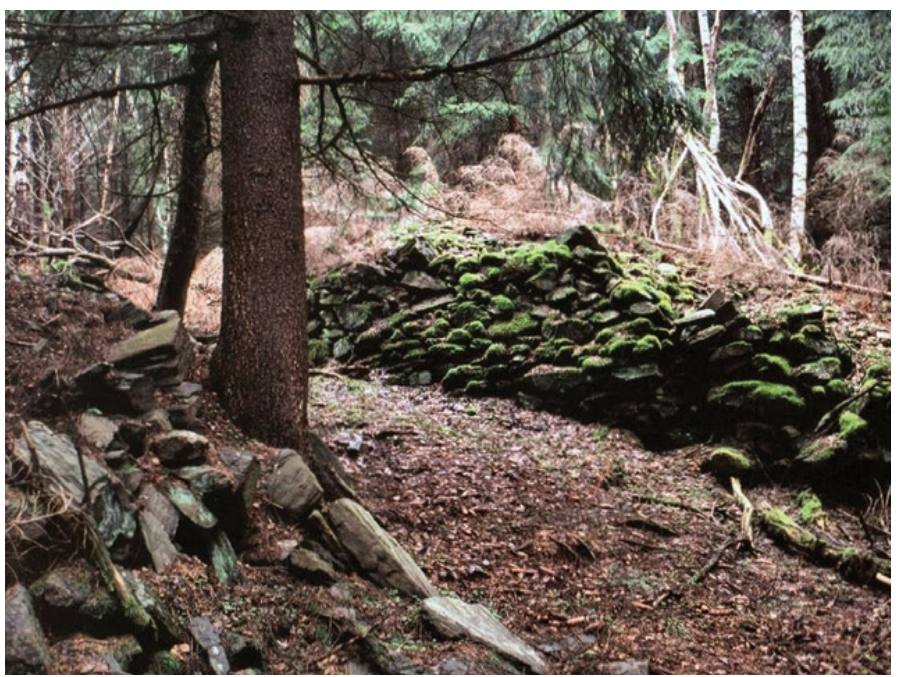

Figure 2. Stone heaps on former fields, nowadays in the forests. 


\section{Changes in the structure of built-up rural areas}

Depopulation of the Sudety Mountains was associated with a change in the structure and density of building in hilly rural areas. There were certain villages that even 'disappeared' altogether (like Wrzosówka, Rogóżka, Biała Woda and Budniki) these mainly being localities that were difficult of access, inter alia because they were small settlements located on the higher parts of slopes (Chachaj 1978; Jerkiewicz 1983; Kasprzak \& Szmytkie 2006). Otherwise, the effect in most villages was for areas to become less-densely built-up, with what had earlier been 'compact' villages becoming more strung-out settlements with dispersed buildings. Processes of this kind are most visible in the upper sections of mountain valleys, especially in and around such villages of the Kłodzko region as Jodłów, Goworów, Kamieńczyk or Marcinków.

However, since the end of the 1990s there has been a clearly-developing new trend as regards the management and utilisation of rural areas in the Sudety Mountains. This concerns an intensive development of single-family housing, including of a holiday-home or weekend-home character, extending on to ever-more-elevated slopes and occupying areas that were once parts of villages (Fig. 3). This is a phenomenon also associated with the development of tourist infrastructure, including in particular the intensive emergence of skiing centres, as for example at Zieleniec or Czarna Góra in the Kłodzko region (Fig. 4). In many places, this development of construction and infrastructure has arrested the secondary succession process in vegetation, even to the point where processes of soil erosion are reviving on slopes deprived of their protective plant cover thanks to new developments. In the same way, there is also an increase in amounts of material supplied to the channels of brooks, something that may in future give rise to further changes to the fluvial processes dominating there.

The new single-family housing that is going up is quite often chaotic in nature, as well as making no reference whatever to the older spatial structure of villages that were in existence previously. The consequence of this is disruption to spatial order in hill areas. The style of the houses being built also has little to do with the traditional regional architecture, of which many examples remain in a large number of Sudety villages. None

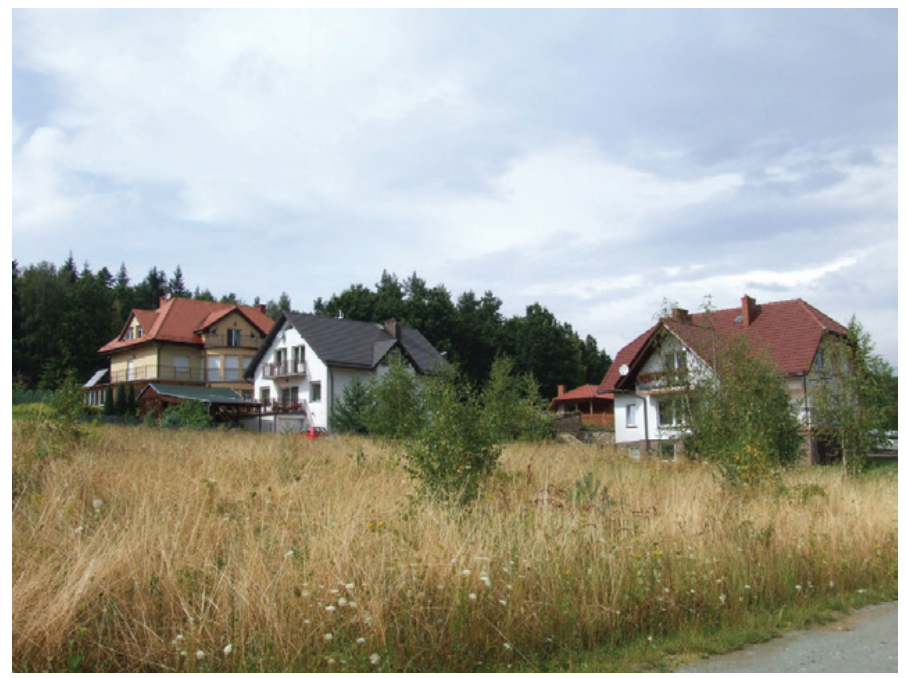

Figure 3. Chaotic pattern of single-family housing encroaching on upper parts of slopes - Maria Hill above Polanica Zdrój.

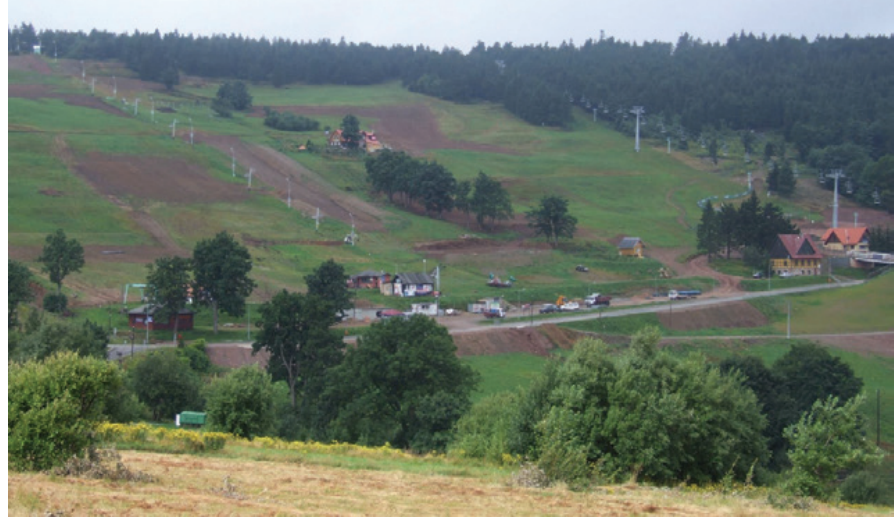

Figure 4. Development of tourist facilities, especially skiing, enhances soil erosion from slopes - Zieleniec. 
of the building activity is encouraging a return to the former functions of villages, hence it is not possible to observe any increase in the area of land in use in agriculture, since the great majority of incomers are either temporary residents at most, or are anyway employed outside farming.

\section{The disappearance of field roads}

A well-marked landscape change associated with the disappearance of the agricultural function in more-elevated parts of slopes involves the disappearance of field roads. The loss of the network of unsurfaced roads by which fields were formerly accessed was estimated by reference to $1: 10,000$-scale topographic maps from the 1970s, as well as field trips made in the most recent periods. An analysis carried out for the Kłodzko region shows how an average of around $50 \%$ of the field roads has been lost in the last 30-40 years, albeit with different sub-regions losing between 27 and $80 \%$ of their roads of this kind, depending on local conditions (Latocha 2007). The old field roads disappear through denudation processes on more-elevated parts of slopes and scarps removing the material that once filled in holes, as well as through roads becoming overgrown. In today's landscape, it is common for an indicator of the courses of old field roads to take the form of preserved belts of trees or scrub crossing fields and being clearly defined as linear elements of the landscape (Fig. 5).

\section{The upgrading of the cultural landscape}

In rural areas of the Sudety Mountains there are an enormous number of items of heritage architecture and mansion-garden complexes formerly constituting an important element of the regional landscape. In the post-war period, changes of ownership ensured that most of these buildings came under state ownership, and were most often put to uses not in line with their original designations. This led to the ruination of many buildings and to what were frequently irreversible changes, including degradation of the cultural landscape.
However, in recent years there have been ever-more examples of attempts being made to restore, renew or upgrade the cultural landscape in the Sudetes. A very good and positive example concerns the Jelenia Góra Basin. Between the 19th and the mid-20th centuries, this area was termed the "Valley of Kings" or "Valley of Castles and Gardens", on account of the exceptional concentration of royal residences or mansions once belonging to the elite of the Prussian Court. The adjacent palace-garden or mansion-garden complexes organised in the English style linked up with one another to create a single larger landscape entity. The ways in which mansions and palaces were constructed, and parks and garden laid out, made ideal use of the existing relief, which included numerous granite elevations and emergent

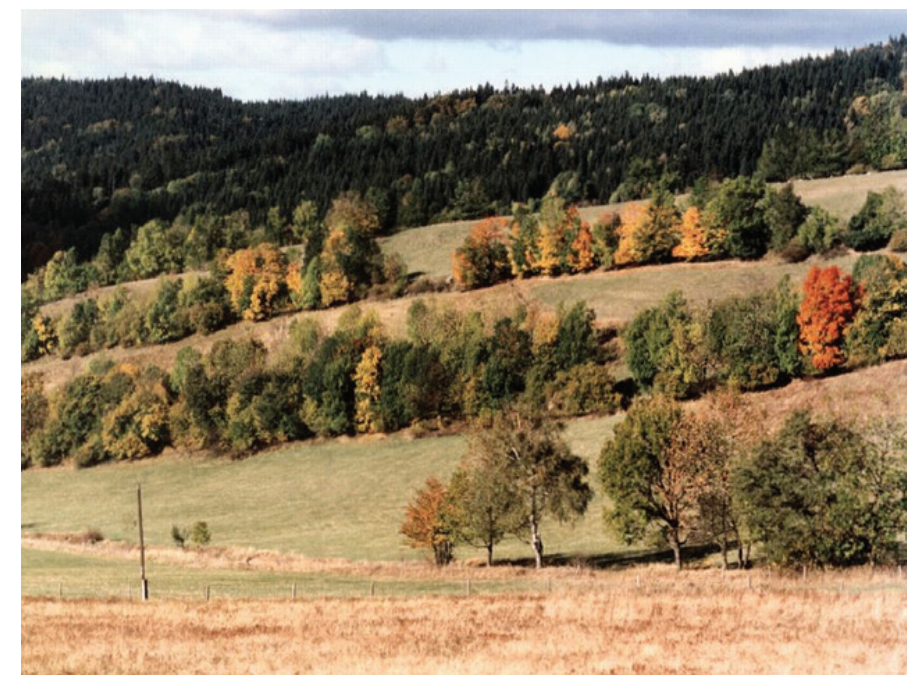

Figure 5. Tree lines are often the only indicator of former existence of field roads, which gradually disappear from the Sudetic landscape.

rockforms (Migoń \& Latocha 2008). The result was therefore a harmoniously developed complex of architectural and landscape layouts.

After the World War II, the systemic changes in Poland led most of the above buildings to fall into disrepair. However, the situation has improved once again in recent years, primarily thanks to the collective activities of inhabitants of the Jelenia Góra Basin, as inter alia associated in the "Karkonosze Forum" organisation seeking to restore the region's landscape and cultural attributes of old times (i.a. Korzeń 2006). For several years now, gatherings of architects have been held under the slogan "budowanie w pięknym krajobrazie" 
("building in a beautiful landscape"), while a grassroots social initiative was crowned with success when, in 2008, Poland's largest culture park was established in the Jelenia Góra Basin, bringing old architectural/garden designs under protection. The now-complete revitalisation of a large part of the old landscaped palace-and-garden layouts has also allowed new functions to be conferred, hotels, restaurants, conference centres and centres for biological renewal being among the establishments and facilities founded. However, in this case the change of function has not translated into any loss of attributes of the cultural landscape. Indeed, quite the reverse is true, as valuable features have been recreated and maintained thanks to the new functions that are to be served.

\section{The re-creation and protection of valuable features of the rural Sudety landscape}

Certain projects being implemented in the Sudety Mountains offer examples of multifaceted activity seeking to achieve sustainable development, in strict connection also with the preservation of valuable landscape features. For example, in the Kłodzko region, within the framework of an FAO-coordinated project ("Sustainable Mountain Development" TCP/POL/3004 (A)), there are several pilot projects completed or in the process of being implemented which have as their main aim to demonstrate the opportunities capable of arising out of the preservation of biological diversity, or even the re-creation of the Mountains' botanical resources; as well as the indication of alternative sources of income from agriculture (Cyron et al. 2007). The projects entitled "Podgórska winnica" ("Foothills Vinyard") and "Sad-kolekcja" ("Orchard-collection", featuring regional varieties of fruit), as implemented in the Radków commune, represent rationally composed elements of the mountain landscape and the saving of endangered varieties on the one hand, and on the other an attempt to establish a set of local products on the basis of old regulations, and with the engagement in cooperation of local people, including young people of school age. This is a good example of the linking-up of responsible and sustainable shaping of the landscape with nature conservation, environmental education and the development of the economy through the establishment of alternative sources of income for the local population. In turn, the "Sudety Meadows" project being pursued at the Mountain Station in Paszków (i.e. a facility of the Lower Silesian Agricultural Advisory Centre in Wrocław) has as its objective a raising of the level of biological diversity, as well as of the quality of a mountain meadow from the point of view of the supply of fodder, the further objective here being to ensure a return to the raising of cattle, sheep and goats in the region. The project has educational and training significance, in that it shows farmers how a degraded meadow may be converted into one that is of value. At Nowy Gierałtów, the "Koziarnia-mleczarnia-serowarnia" project has entailed the establishing of a model goat farm, on which there is training for the pupils of agricultural colleges in the mountainous voivodships as regards the potential for future cheesemaking operations. Further projects that are also of landscape significance are being run within Jugów Forest District, in regard to the "Reintroduction of the yew" as well as the "Collection of wild mountain fruits", association with the introduction into the forest edge and clearings of plantations of biocoenotic trees and shrubs (wild apples and pears, cherry and bird-cherry, sloeberry and wild cornel) (Komornicki 2007).

\section{Summary}

In the years since the end of the World War II, the landscape of rural areas in the Sudety Mountains has undergone a distinct evolution, not only in terms of spatial structure, but also - and above all - as regards functions served. The once-dominant typically economic function, involving agriculture, now has its place taken to an ever greater degree by the aesthetic function served by the landscape, as well as the significance that has for rest and recreation. The rural landscape of the Sudety Mountains is perceived to an ever-greater extent in terms of the potential it offers for economic development based first and foremost around tourism, and there are more and more projects in which the landscape is defined as a 'tourist product' (i.a. the 2008 project under the Regional Development Agency in Nowa Ruda entitled "The landscape as a valuable touristic feature of the Kłodzko region").

Today's Sudety landscape constitutes a kind of unique mosaic formed through the overlap of diverse elements comprising the overall landscape structure and relating to the region's complex 
history and economic fate. The changes in landscape to be observed here in the post-war period are seen to be very diversified in spatial terms. Areas with traditional heritage architecture (if mostly in a rather neglected condition) stand adjacent to new built-up areas bereft of any recognisable style, as well as areas in which investment in tourist-related aspects has proceeded beyond what is reasonable or justifiable. Likewise, land brought back into agricultural use, within the framework of agri-environmental programmes, lies adjacent to areas in which spontaneous secondary succession on abandoned land is proceeding apace.

The optimal direction to the future spatial organisation of rural areas in the Sudety region entails the maintenance of balance between old and new landscape elements, with simultaneous upgrading of traditional landscape structures, above all heritage construction (an obvious barrier to this worthwhile process of course taking the form of significant financial constraints). Nevertheless, positive examples suggesting ever-more-frequent

\section{References}

BaC S., 1948. Zdobycze pługa w Kotlinie Kłodzkiej. Rocznik Kłodzki, no. 1, pp. 119-136.

Baldock D., Beaufoy G., Brouwer F., Godeschalk F., 1996. Farming at the margins: Abandonment or redeployment of agricultural land in Europe. London-The Hague: Institute for European Environmental Policy, Agricultural Economics Research Institute, 202 pp.

Bryś K., OjRzyŃska H., 2010. Przemiany krajobrazu wsi górskich w Sudetach Wschodnich. Prace Komisji Krajobrazu Kulturowego, no. 14, pp. 157-173.

ChaCHAJ J., 1978. Problem wsi zanikajacej. Acta Universitatis Wratislaviensis, vol. 324, Prace Instytutu Geograficznego, ser. B 2, pp. 119-123.

Ciok S., 1991. Sudety. Obszar problemowy. Acta Universitatis Wratislaviensis, vol. 1236, Studia Geograficzne, vol. 51, $88 \mathrm{pp}$.

Ciok S., 1994. Rozwój osadnictwa na Dolnym Śląsku po II wojnie światowej. Tendencje i kierunki zmian, Acta Universitatis Wratislaviensis, vol. 1591, Studia Geograficzne, vol. 61, pp. 9-49.

Ciok S., 1995. Zmiany ludnościowe i osadnicze w Sudetach. Acta Universitatis Wratislaviensis, vol. 1730, Prace Instytutu Geograficznego, ser. B 12, pp. 51-64. appreciation of the degree to which it is worthwhile protecting and promoting valuable features of the landscape offer hope for the fullest possible preservation of rural landscape diversity in the Sudetes, along with all the traditional elements associated with it. This might serve to curb the negative trends observable in recent years, including first and foremost the ongoing loss of landscape openness and diversity as a consequence of the intensive development of single-family housing of a chaotic nature, not adjusted to regional specifics; as well as the installation of excessive amounts of tourist infrastructure.

During the preparation of the final version of the article for publication, the author was a beneficiary of the project no. NN 306384539 supported by the Committee of Scientific Research.

Editors' note:

Unless otherwise stated, the sources of tables and figures are the author(s), on the basis of their own research.

Cyron A., Komornicki K., Kutkowska B., Latocha A., MALARSKI R., WASZKIEWICZ J., 2007. Investment assistance for sustainable development of the mountain areas in Poland. FAO "Sustainable Mountain Development TCP/POL/3004(A)". Wrocław: Foundation of Assistance Programmes for Agriculture, $128 \mathrm{pp}$.

FATYGA J., 1998. Procesy erozyjne jako czynnik degradacji środowiska przyrodniczego w Sudetach. Problemy Zagospodarowania Ziem Górskich, vol. 44, pp. 21-33.

FAtyga J., GóreCKI A., 2001. Kształtowanie granic rolno-leśnej i darniowo-polowej w Sudetach. Falenty: Instytut Melioracji i Użytków Zielonych, 322 pp.

JeRKIEWICZ A., 1983. Wybrane problemy ludnościowe i osadnicze w Sudetach. Acta Universitatis Wratislaviensis, vol. 506, Studia Geograficzne, no. 32, pp. 11-21.

Kasprzak M., Szmytkie R., 2006. Etapy rozwoju osady Budniki w górskich warunkach Karkonoszy i ich zapis w środowisku [in:] A. Latocha, A. Traczyk (eds.), Zapis działalności człowieka w środowisku przyrodniczym. Metody badań i studia przypadków, Wrocław: Wydawnictwo "Gajt", 198 pp.

KomORNiCKI K., 2007. Rola organizacji pozarzadowych w zrównoważonym rozwoju ziem górskich - wnioski z programu FAO Sustainable Mountain Development TCP/POL/3004 (A) [in:] FAPA, Zrównoważony rozwój 
obszarów górskich, Warszawa: Fundacja Programów Pomocy dla Rolnictwa, pp. 35-42.

Korzeń J., 2006. Ochrona dziedzictwa kulturowego w Kotlinie Jeleniogórskiej. Waloryzacja założenia w Bukowcu. Zielony Region. Biuletyn organizacji pozarządowych Dolnego Śląska, no. 2(2006)/34, Jelenia Góra: Fundacja Karkonoska, 12 pp.

LATOCHA A., 2007. Przemiany środowiska przyrodniczego w Sudetach Wschodnich w warunkach antropopresji. Acta Universitatis Wratislaviensis, no. 3007, Studia Geograficzne, vol. 80, Wrocław: Wydawnictwo Uniwersytetu Wrocławskiego, $216 \mathrm{pp}$.

LATOCHA A., 2009. Land-use changes and longer-term human-environment interactions in a mountain region (Sudetes Mountains, Poland). Geomorphology, vol. 108 , iss. 1-2, pp. 48-57.

LATOCHA A., 2010. Spatial planning in mountain regions - present trends, threats and opportunities (Sudety Mountains case study) [in:] A. Mizgajski, I. Markuszewska (eds.), Implementation of Landscape Ecological Knowledge in Practice, The Problems of Landscape Ecology, vol. 28, pp. 55-64.

MacDonald D., Crabtree J.R., Wiesinger G., Dax T., Stamou N., Fleury P., Gutierrez Lazpita J., Gibon A., 2000. Agricultural abandonment in mountain areas of Europe: Environmental consequences and policy response. Journal of Environmental Management, vol. 59, pp. 47-69.

Mastalska-Cetera B., 2006. Udziat rolników w ochronie przyrody w Krajowym Programie Rolnośrodowiskowym na terenie Sudetów [in:] M. Furmankiewicz, P. Jadczyk (eds.), Problemy współpracy na rzecz ekorozwoju Sudetów, Jelenia Góra: Muzeum Przyrodnicze, pp. 129-144.

Mastalska-Cetera B., 2008. Możliwości wsparcia finansowego rolnictwa na obszarach Natura 2000 na przykładzie Sudetów [in:] M. Furmankiewicz, B. Mastalska-Cetera (eds.), Problemy wdrażania sieci $\mathrm{Na-}$ tura 2000 na obszarze Sudetów, Jelenia Góra: Muzeum Przyrodnicze, pp. 77-92.
Migoń P., LATOChA A., 2008. Enhancement of cultural landscape by geomorphology. A study of granite parklands in the West Sudetes, SW Poland. Geografia Fisica e Dinamica Quaternaria, 31 (2), pp. 195-203.

MiszeWSKA B., 1989. Zmiany zaludnienia Sudetów w okresie powojennym. Czasopismo Geograficzne, vol. 60, no. 2, pp. 135-145.

PLEWNIAK W., 1978. Zmiany w środowisku geograficznym doliny Dzikiej Orlicy w Górach Bystrzyckich wywołane wyludnianiem wsi. Acta Universitatis Wratislaviensis, vol. 324, Prace Instytutu Geograficznego, ser. B 2, pp. 97-109.

Ротоскі J., 2000. Przemiany użytkowania terenu w Karkonoszach w ciagu ostatnich 100 lat (podłoże spoteczno-ekonomiczne, środowiskowe konsekwencje) [in:] J. Štursa, K.R. Mazurski, A. Palucki (eds.), Geoekologické problémy Krkonoš, Opera Corcontica, vol. 37, pp. 642-649.

SalWICKA B., 1978. Zmiany w zaludnieniu i użytkowaniu ziem wsi górskich Masywu Śnieżnika w strefie granicy rolno-leśnej. Acta Universitatis Wratislaviensis, vol. 324, Prace Instytutu Geograficznego, ser. B 2, pp. 71-87.

SALWICKA B., 1983. Zmiany w zaludnieniu i użytkowaniu gruntów wsi górskich na wybranych obszarach przygranicznych Sudetów Kłodzkich. Acta Universitatis Wratislaviensis, vol. 506, Studia Geograficzne, no. 32, pp. 23-30.

Walczak W., 1968. Dolny Śląsk. Cz. 1, Sudety. Warszawa: Państwowe Wydawnictwo Naukowe, 383 pp.

WolSKI J., 2007. Przekształcenia krajobrazu wiejskiego Bieszczadów Wysokich w ciagu ostatnich 150 lat. Prace Geograficzne, no. 214, Warszawa: Instytut Geografii i Przestrzennego Zagospodarowania PAN, 228 pp.

WoLSKI J., 2009. Następstwa zaniku antropopresji na obszarach górskich - dyskusja zależności "proces a region" w ujęciu różnoskalowym. Przegląd Geograficzny, vol. 81, no. 1, pp. 47-73. 
http://rcin.org.pl 